Asian J. Med. Biol. Res. 2019, 5 (1), 31-36; doi: 10.3329/ajmbr.v5i1.41042

\author{
Asian Journal of \\ Medical and Biological Research \\ ISSN 2411-4472 (Print) 2412-5571 (Online) \\ www.ebupress.com/journal/ajmbr
}

\title{
Article \\ Microbiological quality assessment of raw milk and water samples from Noakhali district, Bangladesh
}

\author{
Asma Talukder ${ }^{1}$, Anuja Saha ${ }^{1}$, Sabrina Binta Shoeb ${ }^{1}$ and Mimma Tabassum ${ }^{2}$ \\ ${ }^{1}$ Department of Biotechnology and Genetic Engineering, Noakhali Science and Technology University, \\ Noakhali-3814, Bangladesh \\ ${ }^{2}$ Department of Statistics, Noakhali Science and Technology University, Noakhali-3814, Bangladesh
}

*Corresponding author: Asma Talukder, Department of Biotechnology and Genetic Engineering, Noakhali Science and Technology University, Noakhali-3814, Bangladesh. E-mail: atalukderbgenstu@ gmail.com

Received: 09 February 2019/Accepted: 14 March 2019/ Published: 31 March 2019

\begin{abstract}
This study was carried out to evaluate the microbial quality of raw milk and water samples taken at four different local shops in Maijdee area (Noakhali District), Bangladesh. Milk is a valuable food-stuff consumed on daily basis and is highly prone to bacterial contamination. Contamination with pathogenic microorganisms is most alarming for potable water and hence it is needed to detect the bacterial contamination in local drinking water. Microbiological quality of milk samples was analyzed using Total Viable Bacterial Count (TVBC), Total Coliform Count (TCC) and Yeast-mold Count techniques. Critical hygienic indicator for food and foodstuffs is total microbial load. Compare to four stores, store 3 shows the high contamination value in milk samples (TVC $12.48 \times 10^{5} \mathrm{cfu} / \mathrm{ml}$, TCC $6.4 \times 10^{5} \mathrm{cfu} / \mathrm{ml}$, yeast- mold count $3.48 \times 10^{2} \mathrm{cfu} / \mathrm{ml}$ and $4.85 \times 10^{2}$ $\mathrm{cfu} / \mathrm{ml}$ ) whereas store 1 is liable to water samples (TVC $12.09 \times 10^{5} \mathrm{cfu} / \mathrm{ml}$, TCC $4.81 \times 10^{5} \mathrm{cfu} / \mathrm{ml}$, yeast- mold count $2.7 \times 10^{2} \mathrm{cfu} / \mathrm{ml}$ and $2.24 \times 10^{2} \mathrm{cfu} / \mathrm{ml}$ ). These outcomes accentuate applying and sustaining proper hygiene practice throughout the manufacturing and distribution to prevent health risks of the rural people.
\end{abstract}

Keywords: water quality; milk contamination; total viable bacterial count (TVBC); total coliform count (TCC); yeast-mold count

\section{Introduction}

A major constituent of diet is milk which quality reliance is essential to a community's health. Milk may get contaminated at various stages such as from cow, extraneous dirt or unclean processing and thus it can contain few organisms (Hayes et al., 2001). Though milk emits nutritional quality and health benefits, it can also serve as an ideal medium for the growth of a wide variety of bacteria (Parekh and Subhash, 2008). Again, milk can be contaminated by improper pasteurization or recontamination. The detection of Coliform bacteria and other pathogens in milk indicates a plausible contamination of bacteria from milk during production, pasteurization and marketing (Bonfoh et al., 2003). Water is life and 60\% of the drinking water is based on surface water resources (Chauret et al., 1995). Surface water bodies are presumed to be more vulnerable to fecal contamination than groundwater reservoirs as natural soil protection and filtration is absent in surface water bodies and possible short distances between the occurrence of contamination and water extraction (Kistemann $e t$ al., 2001). Total Viable Bacterial count (TVBC), also known as total viable count (TVC), is designed to provide an estimation of total number of aerobic organisms in a particular food or drink sample. A series of dilutions of the food/ drink in saline solution is mixed with an agar medium and incubated at $35^{\circ} \mathrm{C}$ for $48 \mathrm{hr}$. Each visible colony is the result of multiplications of a single cell on agar (FAO, 2009). Depending on the product, a high standard plate count may indicate that the product may have been prepared unhygienically or stored inappropriately (NSW Food Authority, 2013). The microbiological assessment of food lead to the classification of microbiological quality into one of the three classes- Satisfactory, Borderline and Unsatisfactory (Centre for 
Food Safety, 2014). Coliform bacteria (Enterobacteriacae) are aerobic, gram-negative and facultative anaerobic, rod-shaped lactose fermentative bacteria that can produce acid (Clesceri, 1998) whereas fecal Coliform is useful indicator of fecal contamination that usually live in the intestines of warm-blooded animals. These coliform bacteria can survive for extended time periods outside the intestines of warm-blooded animals. E. coli and other fecal coliform bacteria can remain viable for several months in water and stream sediments (Davis et al., 2005). Yeasts and molds are another cause to spoil of fermented milk in which the low $\mathrm{pH}$ provides a selective environment for their growth (Fleet, 1990; Rohm et al., 1992). Good manufacturing practices should contain but 10 yeast cells and should have a shelf life of $3-4$ weeks at $5{ }^{\circ} \mathrm{C}$ (Giudici et al., 1996). The aim of the study is to say the overall microbiological quality and to determine the microbial load in milk and water sample collected from local stores.

\section{Materials and Methods}

\subsection{Sample collection}

Four different types of milk as well as water samples were collected from local shops situated in various points of Maijdee city, Noakhali. Approximately $500 \mathrm{ml}$ of each sample were taken aseptically in separate screwcapped wide mouthed plastic containers and then kept at $4{ }^{\circ} \mathrm{C}$ in a sample collector box and were immediately transported to the laboratory for the analysis of several microbiological parameters and after that samples were kept at $0-4{ }^{\circ} \mathrm{C}$ (refrigerator) for further study but not longer than 48 hours.

\subsection{Culture method of total plate count}

$25 \mathrm{ml}$ of each sample were weighted and aseptically added in $225 \mathrm{ml}$ of sterile Buffer Peptone Water then homogenized the mixture in a blender at $600 \mathrm{rpm}$ for $10-15 \mathrm{~min}$ and diluted up to $10^{-5}$ times. The total viable bacterial count was carried out by the spread plate technique (ISO 4833:2003). The diluted sample (1 ml) of each dilution was inoculated into Plate Count Agar for Total Viable Bacterial Count (TVBC) using pour plate technique (Marjan et al., 2014). The plates were screened for the presence of discrete colonies after incubation period and the actual numbers of bacteria were estimated as colony forming unit in per $\mathrm{ml}(\mathrm{cfu} / \mathrm{ml})$.

\subsection{Culture method of total coliform}

$1 \mathrm{ml}$ and $0.1 \mathrm{ml}$ of sample to $3 / 5$ tubes of Lauryl Tryptose Broth (LST) media (each tube contains $10 \mathrm{ml}$ of media). LST tubes were incubated at $35^{\circ} \mathrm{C}$ for $24 \pm 2$ hours for gas production (i.e., displacement of medium in fermentation vial or effervescence when tubes are gently agitated). Gas-negative tubes were re-incubated for an additional 24 hours and confirmed test on all presumptive positive (gas) tubes (ISO 4831:2006. and ISO 7251:2009. Geneva). From each gas forming LST tube, a loopful of suspension was transferred to a tube of Brilliant Green Bile Broth (BGLB) media (each tube contains $10 \mathrm{ml}$ of media). BGLB tubes were incubated at $35^{\circ} \mathrm{C}$ and examined for gas production at $48 \pm 2$ hours. If gas-positive BGLB tube showed a pellicle, Gram staining was performed to ensure that gas production was not due to Gram-positive, lactose-fermenting bacilli. Calculation was done by Most Probable Number (MPN) of coliforms based on proportion of confirmed gas producing LST tubes for three consecutive dilutions. $10 \mathrm{ml}, 1 \mathrm{ml}$ and $0.1 \mathrm{ml}$ of sample were added to 3 tubes of LST-MUG (4-methylumbelliferyl-beta-D-glucuronide incorporated into lauryl tryptose broth) media (each tube contains $10 \mathrm{ml}$ of media). Tubes were then incubated at $35^{\circ} \mathrm{C}$ for $24 \pm 2$ hours for gas production. Gas-negative tubes were re-incubated for an additional 24 hours and confirm test was performed on all presumptive positive (gas) tubes. Both positive and negative tubes were incubated for 24 to $48 \pm 2$ hours at $35{ }^{\circ} \mathrm{C}$. Positive colonies were counted by culturing them in Plate Count Agar (PCA) media.

\subsection{Culture method of yeast and mold}

The total yeast and mold count of the collected dairy products are enumerated according to ISO 21527-2:2008. Using a sterile pipette, $0.1 \mathrm{ml}$ of the test sample or $0.1 \mathrm{ml}$ of the initial suspension was transferred to one Rose Bengal Chloramphenicol Agar (RBC) agar plate. Using a fresh sterile pipette, $0.1 \mathrm{ml}$ of the first decimal dilution was transferred to a second RBC agar plate. These operations with subsequent dilutions were repeated, using a new sterile pipette for each decimal dilution. The liquid over the surface of the agar plate was spread with a sterile spreader until the liquid is completely absorbed into the medium. Then the prepared plates were incubated aerobically, lids uppermost, in an upright position in the incubator at $25^{\circ} \mathrm{C} \pm 1{ }^{\circ} \mathrm{C}$ for 5 days. 


\section{Results and Discussion}

\subsection{Total viable bacterial count (TVBC) in milk and water samples}

Total microbial load of any sample is an important hygienic indicator for food and food staffs. Figure 1 represents the Total Viable Bacterial Count of different samples.

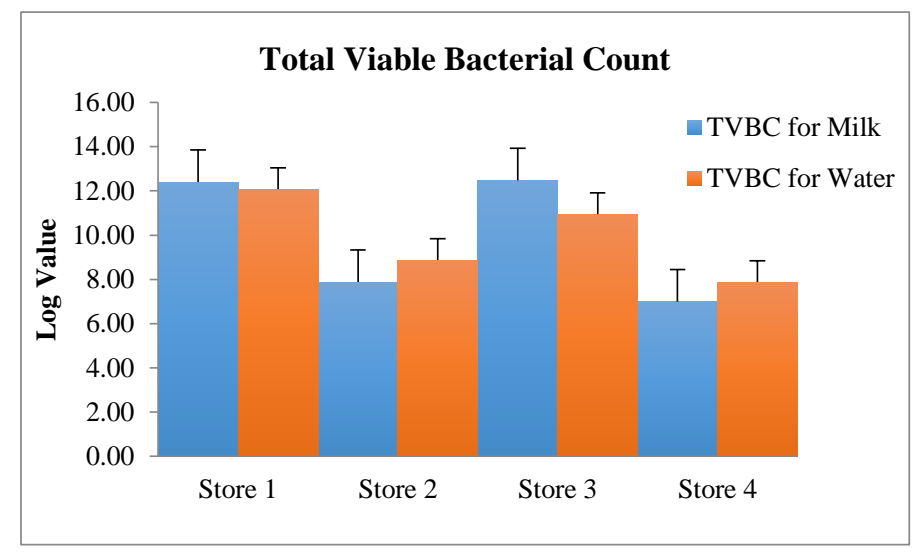

Figure 1. Total viable bacterial count of milk and water samples.

All milk samples had high microbial load ranged in between $7.0 \times 10^{5}$ to $1.24 \times 10^{6} \mathrm{cfu} / \mathrm{ml}$ which is higher than the acceptable level suggested by BSTI (Bangladesh Standards and Testing Institution). This bacterial load is normally due to poor cleaning system of milking. In other study, the bacterial count in milk samples was from $7.5 \times 10^{7}$ to $1.24 \times 10^{8} \mathrm{cfu} / \mathrm{ml}$ (Hossain et al., 2010; Hasan et al., 2015) revealed that total viable count (TVC) of bacteria for raw milks was from $\log 6.29$ to $\log 5.87$. Raw milk contained an average TVC of $1.338 \times 10^{7} \mathrm{cfu} / \mathrm{ml}$ and Pasteurized milk contained an average TVC of $2.95 \times 10^{4} \mathrm{cfu} / \mathrm{ml}$ was depicted by Hussaini et al. (2014). In present study, values ranged in between $7.88 \times 10^{5}$ to $1.21 \times 10^{6} \mathrm{cfu} / \mathrm{ml}$ for water samples higher than the acceptable level suggested by BSTI (Bangladesh Standards and Testing Institution). Among the samples, the highest count was seen in the store-1 and the lowest from Store-4. These results indicate that these examined water samples are not suitable for drinking without purifying. Sarker et al. (2016) found that the bacterial count in water samples was from $17.80 \times 10^{6}$ to $11.46 \times 10^{6} \mathrm{cfu} / \mathrm{ml}$ while bacterial colonies in tap water ranges from the $1.05 \times 10^{4}$ to $2.55 \times 10^{8} \mathrm{cfu} / \mathrm{ml}$ was observed by Hameed et al. (2015). A study was conducted to evaluate the quality of drinking water samples from the four different drinking water sources namely open wells, bore wells, can water and tap water by Sailaja et al. (2015) and showed that the total viable count of the Open well water is highest $\left(95 \times 10^{4}\right.$ bacteria/ ml $)$ and lowest in are also high in open well water $\left(10.75 \times 10^{4} \mathrm{spores} / \mathrm{cm}\right)$.

\subsection{Total coliform count (TCC) in milk and water samples}

Coliforms were found in all the milk and water samples of the four stores. The range of Coliform count for milk samples is from $6.39 \times 10^{5}$ to $5.85 \times 10^{6} \mathrm{cfu} / \mathrm{ml}$ and for water samples is from $4.81 \times 10^{5}$ to $2.62 \times 10^{6} \mathrm{cfu} / \mathrm{ml}$ (Figure 2).

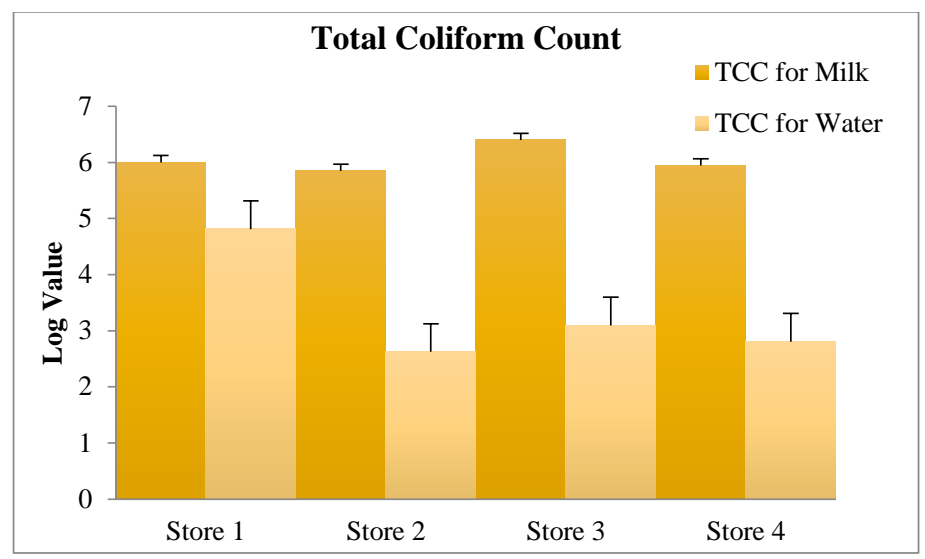

Figure 2. Total Coliform count of milk and water samples. 
Coliform count of these milk samples can give the consideration of it as an unhygienic food and pose a serious threat to the public health. Ogot et al. (2015) studied that among all the examined samples, Coliform count in $60 \%$ of the raw milk samples was $>50000 \mathrm{cfu} / \mathrm{ml}$ while the number is reduced after boiling and only $40 \%$ of the boiled samples had $>50000 \mathrm{cfu} / \mathrm{ml}$ Coliforms. Another study showed that the total Coliform and E. coli count was ranged from $3.74 \log \mathrm{cfu} / \mathrm{ml}$ to $4.07 \log \mathrm{cfu} / \mathrm{ml}$ and from $2.06 \log \mathrm{cfu} / \mathrm{ml}$ to $2.98 \mathrm{log} \mathrm{cfu} / \mathrm{ml}$ respectively for milk samples (Mohamed et al., 2017). Banik et al. (2011) published that the range of total Coliform count in raw milk samples collected from different areas of Dhaka city was from $8 \times 10^{6} \mathrm{cfu} / \mathrm{ml}$ to $1.0 \times 10^{4} \mathrm{cfu} / \mathrm{ml}$. Another study was conducted by Ohanu et al. (2012) and he expressed an evidence of Coliform contamination in all the samples of sachet and tap water.

\subsection{Average count of yeast and mold in milk and water samples}

Average count of yeast and mold is another hygiene indicator that reveals the cleanliness of a sample. The results of average Yeast count and Mold count of this study are set out at figure 3 and 4 . These results show the hygiene quality of these samples were low as higher number can deteriorate the sensory properties of milk and influence the taste defect and foreign off-flavor. Mohamed et al. (2017) enumerated another study of yeast and molds and count of yeast-mold ranged significantly from 5.28 to $5.96 \mathrm{log} \mathrm{cfu} / \mathrm{ml}$ and with mean value $5.54 \log$ $\mathrm{cfu} / \mathrm{ml}$.

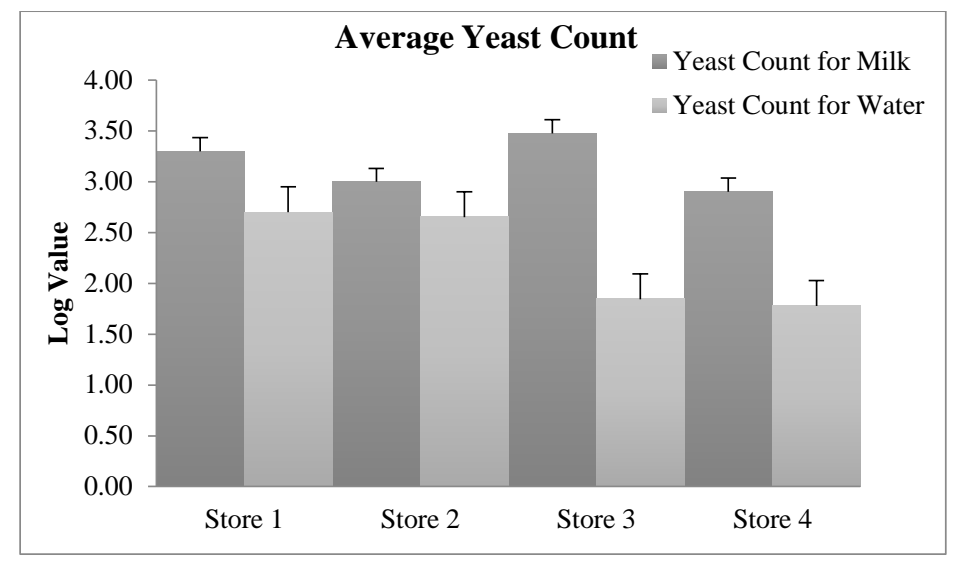

Figure 3. Average count of yeast in milk and water samples.

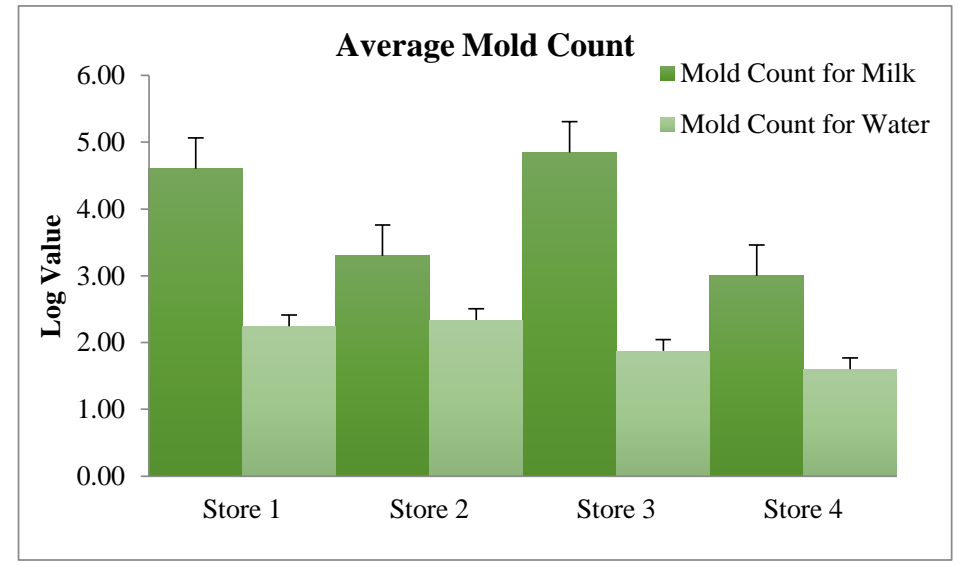

Figure 4. Average count of mold in milk and water samples.

Another study showed that yeasts and molds count of retailer shops milk samples $\left(2.17 \times 10^{4} \pm 5.22 \times 10^{2} \mathrm{cfu} / \mathrm{ml}\right)$ was significantly high followed by dairies $\left(1.94 \times 10^{4} \pm 3.86 \times 10^{3} \mathrm{cfu} / \mathrm{ml}\right)$ and dairy farm milk samples $\left(1.80 \times 10^{4}\right.$ $\pm 4.42 \times 10^{3} \mathrm{cfu} / \mathrm{ml}$ ) (Shah et al., 2016). A study conducted by Mohamed et al. (2017) showed some filamentous fungal species such as Aspergilllus spp., Penicillium spp., Fusarium spp. and Mucor spp., and additionally showed presence of some yeasts such as Saccharomyces cerevisiae and Candida spp. This study showed that milk samples were comparatively more microbiologically contaminated than the water samples. Microbial count may be high due to milk in dirty udders, unclean conditions of milking, dirty housing environment and failing to 
cool milk rapidly at less than $40^{\circ} \mathrm{F}$. Most water sources in this study were also microbiologically polluted. The effects were attributed to poor source of water protection, poor sanitation and low level of hygiene practices and lack of monitoring and healthcare awareness. Drinking water must be microbes free otherwise it can pose health hazard.

\section{Conclusions}

Availability and comparative lower price of milk and water in local stores make people to drink them. However, the findings of present study reveal that the water and milk samples are contaminated with microbial load so that these are not good for health. In further study, identification of the organisms makes it more significant to aware peoples about standard regulations as well as legislations to ameliorate their health.

\section{Conflict of interest}

None to declare.

\section{References}

Banik SK, KK Das and MA Uddin, 2014. Microbiological quality analysis of raw, pasteurized, UHT milk samples collected from different locations in Bangladesh. S. J. Microbiol., 4: 5-8.

Bonfoh B, A Wasem, AN Traore, A Fane, H Spillmann, CF Simbe, IO Alfaroukh, J Nicolet, Z Farah and J Zinsstag, 2003. Microbiological quality of cows' milk taken at different intervals from the udder to the selling point in Bamako (Mali). Food Control, 14: 495-500.

Centre for Food Safety, 2014. Microbiological Guidelines for Food (For ready-to-eat food in general and specific food items). The Centre for Food Safety, Food and Environmental Hygiene Department, Hong Kong.

Chauret C, N Armstrong, J Fisher, R Sharma, S Springthorpe and S Sattar, 1995. Correlating Cryptosporidium and Giardia with microbial indicators. J. Am. Water Works Assoc., 87: 76-84.

Clesceri LS, 1998. Standard Methods for the examination of water and waste water: In Collection and Preservation of Samples and Metals. APHA, AWWA, WEF, Washington, DC, USA.

Davis RK, S Hamilton and J Van-Brahana, 2005. Escherichia coli survival in mantled karst springs and streams, northwest Arkansas Ozarks, USA. J. Am. Water Resour. Assoc., 41: 1279-1287.

Fleet GH, 1990. Yeasts in dairy products. J. Appl. Bacteriol., 68: 99-211.

Food and Agriculture Organization of the United Nations (FAO), 2009. Rome, ISBN 978-92-5106215-9.

Giudici P, G Masini, and C Caggia, 1996. The role of galactose fermenting yeast in plain yogurt spoilage. Ann. di Microbiol ed Enzimol., 46: 11-20.

Hameed U, AB Muhammad, A Jahngeer and I Haq, 2015. Determination of Microbial Load of Drinking Water from Different Areas of Lahore. Biologia (Pakistan), 61: 151-156.

Hasan MA, MA Islam, MS Mahmud, AA Uddin and S Ahmed, 2015. Microbial analysis of raw and pasteurized milk from selected areas of Dinajpur, Bangladesh. Asian J. Med. Biol. Res., 1: 292-296.

Hayes MC, RD Ralyea, SC Murphy, NR Carey, JM Scarlett and KJ Boor, 2001. Identification and Characterization of Elevated Microbial Counts in Bulk Tank Raw Milk. J. Dairy Sci., 84: 292-298.

Hossain TJ, K Alam and D Sikdar, 2010. Chemical and microbiological quality assessment of raw and processed liquid market milks of Bangladesh. Res. J. Dairy Sci., 4: 28-34.

Hussaini SZ, M Shaker, RM Gulve and MA Iqbal, 2014. Bacterial Analysis of Raw and Packed Milk of Beed City. Journal of Advances in Applied Sciences and Technology, 1: 53-58.

International Organization for Standardization (ISO), 2003. Microbiology of food and animal feeding stuffsHorizontal method for the enumeration of microorganisms-Colony count technique at $30^{\circ} \mathrm{C}$. ISO 4833:2003. ISO, Geneva.

International Organization for Standardization (ISO), 2006. Microbiology of food and animal feeding stuffshorizontal method for the detection and enumeration of coliforms - most probable number technique. ISO 4831:2006. ISO, Geneva.

International Organization for Standardization (ISO), 2008. Microbiology of food and animal feeding stuffsHorizontal method for the enumeration of yeasts and molds, Part-2 colony count technique in products with high water activity less than or equal to 0,95 . ISO 21527-2:2008. ISO, Geneva.

International Organization for Standardization (ISO), 2009. Microbiology of food and animal feeding stuffs. Horizontal method for the detection and enumeration of E. coli- Most probable number technique. ISO 7251:2009. ISO, Geneva. 
Kistemann T, F Dangendorf and M Exner, 2001. A geographical information system (GIS) as a tool for microbial risk assessment in catchment areas of drinking water reservoirs. Int. J. Hyg. Environ. Heal., 203: 225-233.

Marjan S, KK Das, SK Munshi and R Noor, 2014. Drug-resistant bacterial pathogens in milk and some milk products. Nutr. Food Sci., 44: 241-248.

Mohamed AF, AE Fourreh, AA Okieh, CN Said and A Mérito, 2017. Evaluation of Microbiological Quality of Raw Milk from Farmers and Dairy Producers in Six Districts of Djibouti. J. Food Microbiol. Saf. Hyg., 2: 124.

NSW Food Authority, 2013. Details - Register of offences (prosecutions). http://www.foodauthority.nsw.gov.au/news/offences/prosecutions/offences-details-tables-restaurant/. Accessed 25 January 2013.

Ogot HA, HO Ochuodho and R Machoka, 2015. Microbial analysis of raw and boiled milk sold at Baraton center in Nandi County, Kenya. In Proceedings of the Second Annual Baraton International Interdisciplinary Research Conference Proceedings 2015 Emerging Issues in Globalization, Baraton Interdisciplinary Research Journal, 1-8.

Ohanu ME, P Udoh and CI Eleazar, 2012. Microbiological Analysis of Sachet and Tap Water in Enugu State of Nigeria. Adv. Microbiol., 2: 547-551.

Parekh TS and R Subhash, 2008. Molecular and Bacteriological Examination of Milk from Different Milch Animals with Special Reference to Coliforms. Cur. Res. Bacteriol., 1: 56-63.

Rohm H, F Eliskasses and M Bräuer, 1992. Diversity of yeasts in selected dairy products. J. Appl. Bacteriol., 72: $370-376$.

Sailaja V, P Umamaheswari, DK Kanderi, PK Reddy and G Rajoji, 2015. Physicochemical and Microbiological analysis of Municipality Drinking Water. Int. J. Curr. Res., 7: 19368-19372.

Sarker A, S Dash, MM Hoque, S Ahmed and MR Shaheb, 2016. Assessment of microbial quality of water in popular restaurants in Sylhet city of Bangladesh. Bangladesh J. Agric. Res., 41: 115-125.

Shah T, QA Shah, JM Shah, MA Arain, M Saeed, FA Siyal, RN Soomro and SA Brohi, 2016. Microbiological Quality of Raw Milk and Associated Health Risk in the Hyderabad Region of Pakistan. Int. J. Food Nutr. Saf. 7: 61-77. 